\title{
USE OF ONLINE SHOP IN INSTAGRAM IN WOMEN'S CONSUMPTIVE BEHAVIOR IN JAKARTA
}

\author{
Fauziah \\ Dosen Universitas 17 Agustus Jakarta \\ Email : fauziah_yanis@yahoo.com
}

\begin{tabular}{ll}
\hline ARTICLE INFO & ABSTRACT \\
\hline Keywords: & The rise of shopping through online stores on Instagram makes women in Jakarta a \\
Online Shop, & problem in this case. Generally women do online shopping not only on the mere needs, \\
Consumptive behavior, & for the sake of and the lifestyle of a country called wasteful or better known as \\
Women & consumptive behavior or consumerism behavior. This study used qualitative research \\
& methods. The results of research conducted on six people obtained information from \\
& online consumer behavior in Jakarta has entered the consumer category or online \\
& shopping on large Instagram for women, online shopping or online stores are more \\
& interested in shopping problems with reasons and behavior because they are not want \\
& to miss the trend and offer prices from online stores even though the product is not \\
& needed.
\end{tabular}

\section{INTRODUCTION}

Smartphone sophistication allows users to access various social media features or better known as social media. Social media is part of the internet, which is a group of internet-based applications built on the basis of Web 2.0 ideology and technology, and allows the creation and exchange of user-generated content. Web 2.0 is a basic platform for social media (Kaplan \& Haenlin, 2010: 61).

Social networking is a social media that is widely used by the community. Social media is more widely used by the community to communicate and get information because of the sophistication of social media that can present up-to-date information, easily accessible to the wider community only by using cellphones such as smartphones and is a cheap medium. One of the most popular social media and is one of the excellent features on smartphones is Instagram. Instagram is an application to share photos, apply digital filters and share them to various social networking services, including the property of Instagram itself (https://id.wikipedia.org/wiki/Instagram, 7/10/2017). 
Instagram is in great demand in almost all circles, from ordinary people, artists, public figures, government officials and even the President. As one of the social media that is being loved by the people of Indonesia, where through Instagram users can share image content, so accessing Instagram as an exciting activity favored by internet users in Indonesia. This is not surprising, if online businesses start using Instagram to develop their Instagram business as social media today and are no longer used as a media that is only used to express themselves. and socializing in cyberspace, but used by some people to do marketing and buying and selling transactions, better known as online shops.

By shopping online, consumers will get experiences that cannot be obtained when shopping conventionally. At the beginning of its development, an online shop was used by trading companies who decided to try new marketing strategies in cyberspace. But in reality the number of online shops managed by individuals is far more than the trading company. In 1994 the online shop was introduced to the public, the beginning of an online sales system known as e-commerce stands for electronic commerce.

According to Jullian Ding in Halim (2005: 11) ecommerce is a commercial transaction carried out between the seller and the buyer or with another party in the same agreement relationship to send a number of goods, services, or transfer of rights where the commercial is contained in electronic media (media digital) which physically does not require the meeting of the parties and the existence of this media in the public network (closed system). The e-commerce system was first used by companies in the food sector, namely Pizza Hut. E-commerce uses internet facilities to transact. From e-commerce, it is then developing online buying and selling. (Islamy, Daniella Putri, 2005: 4).

A new product Online shop on Instagram usually uses endorsment services to introduce its account to the wider community. Usually the target of the new online shop endorsment is the artists who already have a lot of followers. Not only artists, ordinary users can be used as endorsers of the online shop if they already have a lot of followers and get a lot of likes on uploading their photos, this gives birth to a new term known as "selebgram" (Instagram celebrity).

By shopping online, consumers will get experiences that cannot be obtained when shopping conventionally. At the beginning of its development, an online shop was used by trading companies who decided to try new marketing strategies in cyberspace. But in reality the number of online shops managed by individuals is far more than the trading company. In 1994 the online shop was introduced to the public, the beginning of an online sales system known as e-commerce stands for electronic commerce. 
According to Jullian Ding in Halim (2005: 11) ecommerce is a commercial transaction carried out between the seller and the buyer or with another party in the same agreement relationship to send a number of goods, services, or transfer of rights where the commercial is contained in electronic media (media digital) which physically does not require the meeting of the parties and the existence of this media in the public network (closed system). The e-commerce system was first used by companies in the food sector, namely Pizza Hut. E-commerce uses internet facilities to transact. From e-commerce, it is then developing online buying and selling. (Islamy, Daniella Putri, 2005: 4).

A new product Online shop on Instagram usually uses endorsment services to introduce its account to the wider community. Usually the target of the new online shop endorsment is the artists who already have a lot of followers. Not only artists, ordinary users can be used as endorsers of the online shop if they already have a lot of followers and get a lot of likes on uploading their photos, this gives birth to a new term known as "selebgram" (Instagram celebrity).

There are about 15 online shops on Instagram that are in great demand for women in Jakarta, including: Onlin @ thebipolaire, @maven_id, @jolie_clothing, @shopasiro, @ shop_primorie and @olshopfany. Most of these online shops sell women's shoes and accessories at affordable prices and the models are up to date.

This is what attracts Instagram apart from various photos so that with the various facilities offered, it causes continuous purchases or consumptive behavior. The results of research conducted by the Indonesian Internet Service Providers Association (APJII) in collaboration with the University of Indonesia's Communication Studies Center (PusKaKom) on 2000 internet users in 42 cities both urban and rural in Indonesia, based on the age of users, the majority of internet users in Indonesia are 18- 35 years is almost half of the total number of users in Indonesia (49\%). This means that it can be said that the segment of internet users in Indonesia are those who fall into the "digital natives" category, namely this age category has a very active character using digital technology networks and has the ability to operate internet-based technology. (http://www.slideshare.net/internetsehat/profil-pengguna-internet-indonesia-2014-riset-oleh-apjiidan-puskakom-ui, 8/11/2017).

Based on the results of research conducted by APJII, the majority of online shopping practitioners are women who are the largest internet users in Indonesia. Women's character is dynamic, likes to socialize, communal society (like to gather and communicate or hang out), besides women are people who talk about something new and social interaction. These characters suggest that women are in an effective dimension, but women are also in an ambiguity position that is often used as a target market that pushes them into the consumption dimension and often they are 
affected by the effects of negative access to globalization, such as consumerism and hedonism. The occurrence of changes in the lifestyle of women today is inseparable from changes in culture, the mindset adopted by the community concerned (Chaney, 2006: 39).

Women are one who is potentially active in using social networking sites. Women's consumption patterns through online shop on Instagram, especially consumption of fashion products, have recently increased. Women are interested in consuming fashion products because they follow the current trend.

High female consumption patterns tend to make consumption. Therefore, the increasing consumption of fashion products today has resulted in an increase in online shopping, which means that there is increasingly an online shop among the community, especially women in Indonesia. This is also offset by the increasing number of online shops popping up on Instagram. The increasing consumption pattern towards a product tends to be consumptive behavior. Consumptive behavior is the act of someone buying an item without a reasonable consideration where someone in buying something is not based on the need factor (Sumartono, 2002).

The consumptive behavior carried out by this woman is no longer to fulfill the needs alone but to fulfill the desire that is to increase prestige, maintain prestige, follow fashion and various other less important reasons.

\section{Formulation of the problem}

Based on the explanation above, the formulation of the problem of this research is "Knowing the use of Online Shop on Instagram in the Consumptive Behavior of Women in Jakarta in 2018".

\section{Research purposes}

The research objective in this study was to find out "How to use online shop on female consumer behavior in Jakarta in 2018"

\section{LITERATURE STUDY}

\section{Marketing Communication}

Marketing communication is an important aspect in the overall marketing mission and important aspects that determine the success of a marketing. In the last decade, the marketing communication component has become one of the important things to consider in order to achieve marketing objectives. All companies or organizations use various forms of marketing communication or promotional mix to promote what they offer and to achieve financial and nonfinancial goals. 
The main forms of marketing communication or marketing mix (promotional mix) include: advertising (advertising), sales promotion, public relations and personal selling. George and Michael Belch added two elements in the promotional mix, namely direct marketing and interactive media (internet marketing). These last two elements have been used extensively to communicate with the target audience as the four previous elements. Internet marketing is part of IMC (Integrated Marketing Communication).

In this study the author wants to see the marketing communication that is carried out by marketing communication conducted by Online Shop that is on Instagram social media with an interactive media or internet marketing promotion mix.

Internet Marketing

Internet marketing is an internet application and related digital technology that is utilized to achieve marketing goals. Internet marketing also includes aspects of planning, pricing, promotion and distribution. Internet marketing also incorporates technical and creative aspects of the internet itself, which includes design, development, advertising and sales.

Rafi A. Mohammed in Veby (2015) defines internet marketing as a process in building and maintaining customer relationships through online activities which are the exchange of ideas, products, services that can meet customer satisfaction. From the explanation above it can be concluded that internet marketing is an activity carried out by utilizing the internet as a means to communicate product promotion and the company itself.

Social Media (Social Media)

Andreas Kaplan and Michael Haenlein define social media as "a group of internet-based applications built on the basis of Web 2.0 ideology and technology, and which enable the creation and exchange of user-generated content".

While Mayfield (2008: 5) in his book What Is Social Media states the indicators of a social media are as follows:

1) Participation

2) Openness

3) Conversation

4) Community

5) Connected to each other

\section{Social Media Marketing}

Social media is one channel that supports communication in marketing merchandise quickly and profitably compared to selling directly to the market. Combining social media with marketing is to support marketing performance along with the development of technology and information. Social 
media marketing is a process that empowers individuals and companies to promote their websites, products or services online and through social channels to communicate with a much larger community that is not available through traditional advertising.

Online Shop on Instagram

Instagram is a special application to share photos with its function to upload photos (upload), take photos (download), edit photos, add digital photo filters (photo effects), comment on photos, give photos, give location photos, mark like on photos, and share photos to various other social networking services (Instagram Handbook, 2012: 8).

There are several features contained in the Instagram application, namely as follows: Followers (Followers), Upload photos (Share), Title Photos (Caption), Mention / Arroba, Hastag, Geotag / Location, Likes (Love / Love), and Comments.

Online shop or online shopping via the internet is a process of buying goods or services from those who sell through the internet, or buying and selling services online without having to meet the seller or the buyer directly. Online shop is not only considered as an election in shopping, but has become part of the socio-cultural changes in society. (Sari, Andira, 2015: 208).

Through an online shop, consumers can see items sold through pictures or even videos. Online Shop has been a lot on Instagram following the growing business and increasing community needs. Items sold almost all on Instagram such as clothes, accessories, bags, books, shoes, cosmetics, children's toys, sports equipment, snacks, and electronic devices can be sold on the social networking site.

Online shop is one form of interactive marketing that has become a shopping trend among today's society. Buying the needs of goods and services through the internet has become a consumer routine today (Kotler, 2007).

\section{Consumptive behaviour}

The act of someone buying an item without a reasonable consideration in which a person is buying an item is not based on the need factor referred to as consumptive action (Sumartono, 2002).

According to Erich Fromm in Fitria, Eva Melita (2015), consumptive behavior has several dimensions, namely Fulfillment of Desires, Goods Out of Reach, Non-Productive Goods, and Status.

Meanwhile, according to Lina and Rosyid (1997) in Daniella Putri Islamy (2015), aspects of consumptive behavior are:

1) Impulsive Buying According to Rook in Kharis (2011), impulsive buying is a purchase that occurs when consumers experience sudden pressure, which is usually very strong and settled to buy things immediately. 
Impulsive buying has several characteristics:

a. Spontaneity b. Strength, compulsive, intensity c. Excitement and stimulation d. Consequence indifference

2) Waste of consumptive behavior as one of the behaviors that waste a lot of funds without realizing that there is a clear need.

3) Purchases Are Not Rational (Non rational buying) A behavior where consumers buy something that is done solely to seek pleasure.

In this study the aspects of consumptive behavior by Lina and Rosyid (1997) in Daniella (2015) are used to measure indicators of consumer behavior in women in Jakarta which fall into the category of shopaholic women.

\section{Kerangka Pemikiran}

Kerangka pemikiran dalam penelitian ini adalah penggunaan online shop yang saat ini marak di masyarakat dan berdasarkan hasil survey perempuan yang paling banyak menggunakan online shop. Instagram adalah salah satu media sosial yang paling banyak dikunjungi karena banyak menawarkan online shop untuk berbagai macam penawaran produk dalam aktifitas komunikasi pemasaran dan internet marketing khususnya fashion. Hal inilah yang mengakibatkan munculnya perilaku konsumtif dikalangan perempuan, karena perempuan dianggap konsumen yang paling sering mengunjungi online shop di intagram dan paling banyak belanja online.

Berikut di bawah ini kerangka pemikiran yang dilakukan peneliti untuk mempermudah jalannya penelitian.

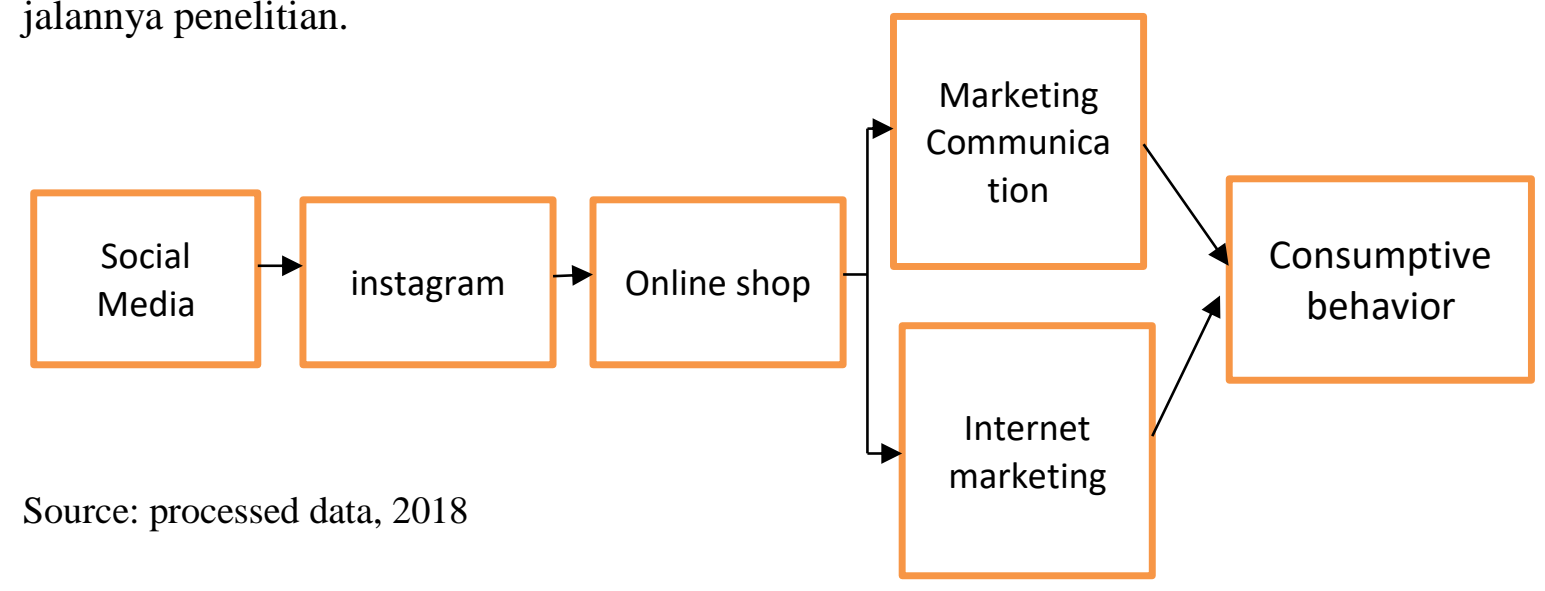

\section{RESEARCH METHODOLOGY}

\section{Research Approach}

The object of this study is that women who live in Jakarta are included in the shopaholic category (online shopping) on Instagram in 2018. This research was conducted using a qualitative descriptive 
research design. Descriptive research was conducted to get an overview or description of the characteristics or characteristics of women who have shopaholic behavior while qualitative analysis as a research procedure that produces descriptive data in the form of written or oral words that are delivered by women who can be observed online shop on Instagram.

\section{Data collection technique}

Data collection procedures are carried out in two ways: Observation through an online shop on Instagram in 2018 and library research. The type of data used is qualitative. The research report will contain citation data to give an overview of the presentation of the report. The informants interviewed were 6 (six) women who actively gave responses and made purchases on onlineshop accounts on Instagram.

\section{Location and Research Schedule}

The location of the research on the online shop on Instagram is @ thebipolaire, @ maven_id, @jolie_clothing, @shopasiro, @ shop_primorie and @olshopfany. The research schedule is conducted from January to March 2018.

\section{Research Result}

The results showed that out of the 6 online shops that were used as research subjects, women were more likely to be online shop followers. The following table lists the number of products sold and their followers:

\begin{tabular}{|l|l|l|l|}
\hline No & \multicolumn{1}{|c|}{ Online Shop } & \multicolumn{1}{|c|}{ Posts } & Followers \\
\hline 1 & Thebipolaire & 47 & 643 \\
\hline 2 & Maven_id & 1212 & $13 \mathrm{k}$ \\
\hline 3 & Jolie_clothing & 1419 & $94,8 \mathrm{k}$ \\
\hline 4 & Shopasiro & 2046 & 9504 \\
\hline 5 & Shop_primorie & 500 & 1104 \\
\hline 6 & olshopfany & 2238 & $227 \mathrm{k}$ \\
\hline
\end{tabular}

Source: processed data, 2018

From the results of interviews with 6 (six) informants regarding the response to product photo posts, videos offered by online shop on Instagram, the following statements were obtained:

1. The informant follows the onlineshop account on Instagram with many followers.

2. Make purchases on onlineshop that have a lot of followers 
3. Giving likes on product photos or videos uploaded online shop on Instagram when attracting attention.

4. The title of the photo (caption) and complete information on product photos and video doposting by online shop on Instagram indicates that the online shop is trusted.

5. Decided to buy the product after reading the complete caption from the product photo or video uploaded on the online shop on Instagram.

6. Utilizing comments from photos or videos uploaded online shop on Instagram to find out the quality of the products and online shop services

7. Make a purchase if the comment on the desired photo or video is positive

While the results of interviews with informants regarding the reasons for preferring online shop shopping compared to conventional shopping found that:

1. Busy, busy and active schedules in the office make it difficult for women to spend time shopping outside the office. By shopping online a woman can shop anywhere, anytime.

2. Time Efficiency, Shopping at malls or regular shops outside the office or outside the home we must be prepared to spend time, jamming, exiting the cost of gasoline or parking, and energy. A lot of time is taken on the road or just to get around looking for the desired item.

3. Comfortable and Stress Free, No need to shop for rushes when selling. This comfort factor is often the main reason many people prefer shopping online. We can shop at any time, even at midnight.

4. Discounts and Promotions, Many ways to get discounts or promotions at online stores. By registering an email, you can get a discount voucher. Especially if we have become loyal customers, many promotional programs can be enjoyed, such as discounts, free shipping. Massive discounts and promotions from online shops are very effective in attracting people so they prefer to shop online than to malls or offline stores.

The results of the interview regarding the consumptive behavior of the informants after seeing the products offered in the form of photos or videos on Instagram obtained a statement that:

1. Immediately buy clothes or accessories or shoes or cosmetics that are offered online shop on Instagram when they feel fit

2. Buy products on the online shop account on Instagram that I want even though the product doesn't really matter

3. Spend some money to buy the product I want on an online shop on Instagram

4. Always feel satisfied after buying the product I want on the online shop on Instagram

5. Shop online at online shops on Instagram almost every month because they are always interested in new models or products 
6. Buy products on the online shop on Instagram according to the latest trends to look cool

\section{Discussion}

Online shop is a facility or shop that offers goods and services via the internet. Consumers at the online shop can see the items directly in the form of pictures or photographs and in the form of videos. Usually, items sold by the online shop are limited edition items and are usually not available in shops or markets. Thus, this condition makes people more interested to shop online.

Instagram is indeed a trend. Instagram is a social media used to share photos and short videos that can be shared with account users. The function is then used by some people to upload photos of online shop products with the classification of goods and the price of the product. This makes everyone who is accessing Instagram instantly see the products sold online along with the classification and price of the product. This will make it easier for consumers to choose the preferred product. Because, in Instagram you can also find several products from several online shops at the same time.

This is a benefit that can be obtained by consumers from an online shop. The growing development of online shop on Instagram as a place to sell a product also makes the shopping behavior shift especially for women.

this is because consumers have the opportunity to interact and consult directly with the seller. For example, in the sale and purchase transaction in the fashion sector.

The tendency to shop via social media also corresponds to the results of a survey by the Indonesian Internet Service Providers Association (APJII) in 2016. The data shows that Indonesian consumers prefer shopping through social media rather than websites. Of the total 132.7 million internet users in Indonesia, as many as 82.2 percent or 62 million people claim to visit the online shop more often, selling their merchandise through social media, such as Fecebook and Instagram. With 46.1 million people saying that the frequency of online shopping transactions can be done more than once a month.

The presence of a variety of products that can be accessed in instagram, makes it easier for someone to find an item or product that they want. In addition, items that have been posted on Instagram are also able to persuade people, especially women, who are basically women who like shopping. So that when a woman gets the ease of accessing Instagram and gets a detailed classification of the item or product, then a woman as a consumer can directly know the quality of the items posted on the Instagram.

This is what makes women prefer shopping through online shop compared to conventional shopping. Besides the demands of being a woman to always change her appearance in accordance 
with the times and the development of current fashion. Changes in appearance ranging from clothing and cosmetics that are supporting the appearance. The behavior of women who buy these products based on the times and the development of appearance mode is a consumptive behavior that derives influence from external individuals.

Tambunan (2001) explains that consumptive behavior arises because individuals follow the mode in circulation, want to look different and tend to never be satisfied with what they have. Furthermore Tambunan (2001) also mentions that such behavior is due to the external factors that influence it in the form of reference groups. The presence of the influence of this reference group makes women tend to be more adapted to the existence of group norms in order to get acceptance and not be rejected.

However, women's behavior in consuming online products can also be classified as internal influences as well. Because in the internal influence there is a personality factor, which according to this theory the personality of each woman will determine and reflect on how a person responds to his environment. If the environment of a woman is experiencing a change in dress style, then automatically the woman as a member of the environment will adjust to also make changes to her style of dress according to her psychological personality. In this adjustment process later women try to obtain various appearance equipment that suits their personality such as buying clothes, watches, or bracelets as accessories for supporting the appearance.

This is one of the characteristics of consumer behavior possessed by women. As the opinion expressed by Sumartono in Astuti (2013), shows that when consumers or women are interested in the product images contained in instagram which then make the woman interested in buying them, the purchase of these items can be stated due to attractive product packaging. With this attractive product display, women are interested in purchasing goods because there are packaging that is different from the others. The packaging of an interesting and unique item will make someone buy the item. Moreover, goods sold in online shops are generally updated items and are in great demand and the prices are relatively cheaper compared to prices at the store.

\section{CONCLUSION}

From the results of the study it can be concluded that:

1. Online shop users on Instagram are mostly women

2. Shopping online or online shop is more attractive than conventional shopping for efficiency reasons.

3. Consumptive behavior arises among others because they do not want to miss the trend and offer cheap prices from the online shop even though the product is not needed. 


\section{REFERENCES}

Atmoko, Bambang Dwi. 2012. Instagram Handbook. Jakarta : Media Kita

Chaney,David.2006. ”Lifestyles Sebuah Pengantar Komprehensif, Yogyakarta, Penerbit :Jala Sutra

Halim, Abdul, 2005, “Analisis Investasi, Edisi Ke-2”, Jakarta, Penerbit : Salemba Empat

Kaplan, Andreas M dan Michael Haenlin., 2010. User of The World, Unite! The Challenges and Oppertunities of Social Media. Jakarta : Kompas Gramedia

Kriyantono, Rachmat. 2010. Teknik Praktis Riset Komunikasi. Jakarta : Kencana Predana Media Group

Kotler, Philip. 2005. “Manajemen Pemasaran. Jilid Satu. Edisi Kesebelas” Alih Bahasa. Benyamin Molan. Jakarta

Mayfield, Anthony, 2008. What Is Sosial Media.ICrossing.

Sugiyono. 2008. Metode Penelitian Kuantitatif, Kualitatif dan R\&D. Bandung : Alfabeta

Sumartono. 2002. "Terperangkap dalam Iklan : Meneropong Imbas Pesan Iklan Televisi:; Bandung : Penerbit Alfabeta

$\underline{\text { Jurnal : }}$

Islamy, Daniella Putri. 2016. "Pengaruh Online Shop Pada Media Sosial Instagram Terhadap Perilaku Konsumtif Siswa-Siswi SMP Cikal Harapan I Bumi Serpong Damai : BSD Kota Tangerang Selatan. UIN Syarif Hidayatullah Jakarta”.

Veby Kusuma Wardhani, 2014. Pengaruh Pengalaman Kerja, Independensi, Integritas, Obyektivitas dan Kompetensi Terhadap Kualitas Audit. Jurnal Ekonomika-Bisnis Vol.5 No.1 Januari 2014. Universitas Brawijaya Malang

Sari, Chacha Andira. 2015. Perilaku Berbelanja Online di Kalangan Mahasiswi Antropologi Universitas Airlangga. AntroUnairdotNet Vol. 4 No. 2

Irfani, Fitri. 2012. Pengaruh Iklan Fashion Majalah Terhadap Perilaku Konsumtif Siswa SMAN 2 Kota Tangerang Selatan. UIN Syarif Hidayatullah Jakarta

\section{Internet :}

https://id.wikipedia.org/wiki/Instagram, 7/10/2017

http://www.slideshare.net/internetsehat/profil-pengguna-internet-indonesia-2014-riset-oleh-apjiidan-puskakom-ui, 8/11/2017 